\title{
ON THE LOCALISATION OF ANTIGENIC DETERMINANTS IN A BENCE JONES PROTEIN
}

\author{
H. G. VAN EYK* AND K. MYSZKOWSKA**
}

Laboratory for Physiological Chemistry, The University, Utrecht (The Netherlands)

(Received June I3th, I967)

\section{SUMMARY}

I. The presence of a low molecular weight protein (I.2 S), having antigenic determinants in common with the homologous Bence Jones protein $(3.4 \mathrm{~S})$, has been observed in the urine of a patient with multiple myeloma. Its amino acid composition and $\alpha-\mathrm{NH}_{2}$-terminal amino acid residue make it likely that the I.2 S component is a protein representing the $\mathrm{NH}_{2}$-terminal, variable, moiety of the Bence Jones protein.

2. After digesting Bence Jones protein (type K, InV(a-)) with pepsin, an antigenically active peptide could be isolated via immunoprecipitation with the homologous antiserum. From its amino acid composition this peptide appears to be located at the $\mathrm{COOH}$-terminal end of the Bence Jones protein, i.e. in the constant part of the polypeptide chain; it must perforce contain the group-specific antigenic determinant.

Numerous investigations ${ }^{\mathbf{1}-4}$ have established that Bence Jones proteins have one of two antigenic determinants in common, either determinant $\mathrm{K}$ or determinant $\mathrm{L}$. Besides this "general" determinant they also possess one or more "specific" determinants that are either unique or only shared with a few other proteins",

Recently, the amino acid sequence has been determined of several Bence Jones proteins, both of type $\mathrm{K}$ and type L. From these studies ${ }^{\mathbf{7 - 9}}$, the light chains of which these proteins are made up appear to consist of two parts, a variable moiety comprising the first I07 amino acids, followed by a constant moiety comprising the next 107 amino acids, from no. Io8 down to the COOH-terminal end.

If this is indeed always the case, it is reasonable to assume as a working hypothesis that the "general" or group-specific determinant could be localized in the constant part of the polypeptide chain, and the more highly specific "individual" determinants in the variable part.

In this paper we wish to present evidence in support of this hypothesis by re-

* Present address: Medical Faculty, Department for Chemical Pathology, Dijkzigt Iospital, Rotterdam, The Netherlands.

** Present address: Institut Leków, Warsaw, Poland. 
porting experiments carried out with protein excreted by one of our multiple myeloma patients (No. I25).

\section{MATERIALS AND METHODS}

The chemicals used were of analytical reagent grade.

Total protein was isolated by precipitation from the urine with ammonium sulphate as described earlier ${ }^{10}$. The purification of the proteins by gel filtration on Sephadex and the preparation of the antisera used have been described in an earlier publication ${ }^{13}$. Immunoelectrophoresis, Ouchterlony gel diffusion tests, methods for amino acid analysis, ultracentrifugation analysis, high-voltage electrophoresis and the determination of $\alpha-\mathrm{NH}_{2}$-terminal amino acids by the Edman procedure were carried out as described in an earlier paper ${ }^{10}$. The reduction of sulfur bridges with 2-mercaptoethanol and the blocking of free - $\mathrm{SH}$ groups with ethyleneimine are described in full detail elswhere ${ }^{11,12}$.

\section{EXPERIMENTS AND RESULTS}

\section{Fractionation of the crude urinary protein}

Immunological typing of the crude protein No. I25 isolated from the urine showed it to be of type $\mathrm{K}$, InV(a-). The protein was lyophilized, dissolved in $0.05 \mathrm{M}$ ammonium formate buffer and subjected to gel filtration on Sephadex G-75. As Fig. I shows, three peaks were obtained. After ultracentrifugation experiments and amino acid analyses, peak $B$ was identified as the light chain dimer $(3.4 \mathrm{~S})$. The protein under peak $\mathrm{A}(4.8 \mathrm{~S})$ had an amino acid composition identical with that of peak $\mathrm{B}$, and dissociated in $5 M$ guanidine- $\mathrm{HCl}$ to form a $3.4 \mathrm{~S}$ component. Therefore it can be regarded as a Bence Jones polymer. Peak $\mathrm{C}$ represents a lower molecular weight component (I.2 S).

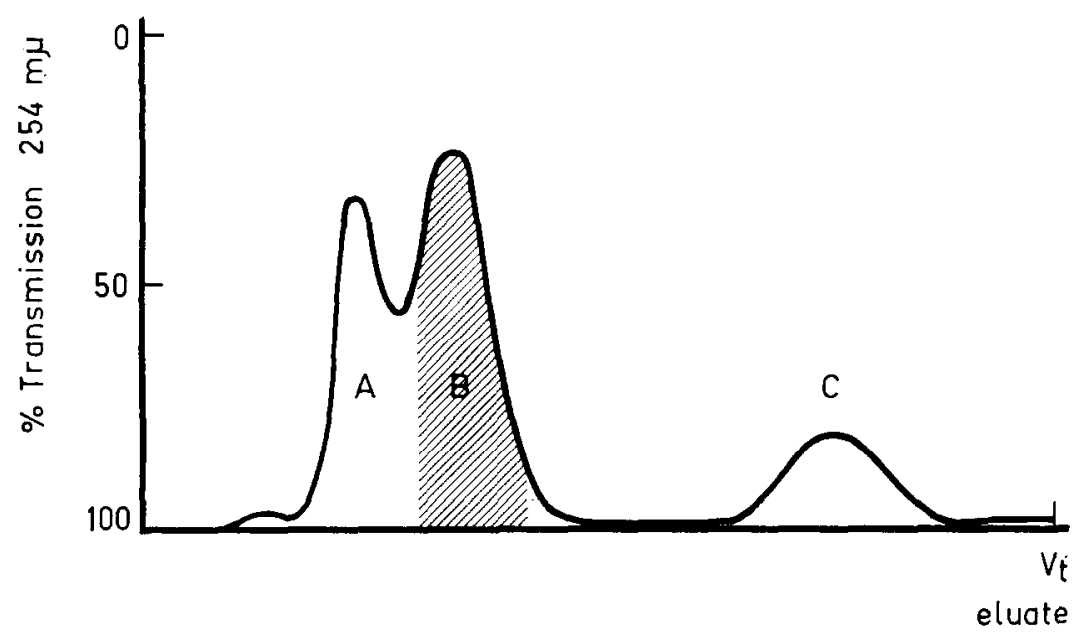

Fig. I. Gel filtration of urinary protein No. 125 on Sephadex G-75. Eluting buffer: $0.05 \mathrm{M}$ ammonium formate. Hatched area: fraction taken for purification of component $B$ by repeated gel filtration. 
Such lower molecular weight components are occasionally found in the company of the main Bence Jones protein. According to a recent investigation ${ }^{5}$ they have some, but not all, antigenic determinants in common with the homologous Bence Jones protein. It has been suggested that they could consist of either the variable or the constant part of the light chain.

\section{Localisation of the group-specific antigenic determinant}

Component $\mathrm{B}$ was obtained in homogeneous state by repeated gel filtration over Sephadex G-75. The purified protein was gently reduced with 2-mercaptoethanol and aminoethylated as described previously ${ }^{11,12}$. Amino acid analysis revealed the presence of only one aminoethyl cysteine residue per 22000 (Table I, column 3).

\section{TABLE I}

AMINO ACID COMPOSITION OF BENCE JONES PROTEIN NO. I25, AND OF PORTIONS OF THE MOLECULE AND RELATED PROTEINS

Component B: Bence Jones No. I25 (dimer).

Component $\mathrm{C}$ : low molecular weight component (see Fig. I).

Number of residues in variable part of component B calculated by subtracting the known composition of the constant part of type $K$ light chains. Total weight of this constant portion of the molecule: 23400 (on dimer basis).

\begin{tabular}{|c|c|c|c|c|c|c|c|}
\hline $\begin{array}{l}\text { Amino } \\
\text { acid }\end{array}$ & $\begin{array}{l}\text { Component } B \\
\text { g/Ioog } \\
\text { protein }\end{array}$ & $\begin{array}{l}\text { Component } C \\
\text { g/too g } \\
\text { protein }\end{array}$ & $\begin{array}{l}\text { Component } B \\
\text { residues } \\
\text { per } 45000\end{array}$ & $\begin{array}{l}\text { Component } C \\
\text { residues } \\
\text { per } 22000\end{array}$ & $\begin{array}{l}\text { Variable } \\
\text { part of } \\
\text { component B } \\
\text { residues } \\
\text { per } 22000\end{array}$ & $\begin{array}{l}\text { Antigenically } \\
\text { active peptide } \\
\text { from } B . \text { No. } \\
\text { of residues }\end{array}$ & $\begin{array}{l}\text { Hilschmann's } \\
\text { COOH-termi- } \\
\text { nal peptide } P_{\mathbf{4}} \\
\text { No. of } \\
\text { residues }\end{array}$ \\
\hline & (I) & (2) & (3) & (4) & (5) & (6) & (7) \\
\hline asp & 9.15 & 8.00 & 36 & I 5 & I 6 & 2 & I \\
\hline thr & $7.8 \mathrm{I}$ & 9.96 & 35 & $2 \mathrm{I}$ & 20 & 2 & 2 \\
\hline ser & 11.45 & 10.73 & 59 & 27 & 27 & 3 & 3 \\
\hline glu & I 4.55 & I 3.49 & 50 & 23 & 24 & 2 & 2 \\
\hline pro & 5.25 & 5.93 & 24 & I4 & I 4 & 2 & 2 \\
\hline gly & 3. I 5 & $4 \cdot 35$ & 23 & 17 & I 7 & 2 & 2 \\
\hline ala & 4.03 & 3.77 & 25 & I I & I I & $\mathbf{I}$ & o \\
\hline val & 6.00 & 3.25 & 26 & 8 & 6 & 2 & 2 \\
\hline met & trace & 0 & 0 & 0 & 0 & 0 & 0 \\
\hline ileu & $3 \cdot 3 \mathrm{I}$ & $5 \cdot 54$ & I 3 & I I & 9 & I & o \\
\hline leu & 7.63 & 7.89 & 32 & I 5 & I 6 & 2 & I \\
\hline tyr & $7.9 \mathrm{I}$ & 9.00 & 22 & 12 & $1_{4}$ & $\mathbf{I}$ & o \\
\hline phe & $5 \cdot 49$ & $5 \cdot 36$ & 17 & 8 & 9 & $\mathbf{I}$ & I \\
\hline lys & 6.98 & 6.34 & 25 & I I & 9 & I & I \\
\hline his & I. 25 & I. 57 & 5 & 2 & I & I & I \\
\hline $\arg$ & 3.85 & $3.8 \mathrm{I}$ & I I & 5 & 5 & I & I \\
\hline$\frac{1}{2}$ cys & I. 67 & 0.80 & 8 & 2 & 2 & o & o \\
\hline cyst AE & 0.69 & o & 2 & o & o & I & I \\
\hline
\end{tabular}

Thereupon the protein was digested with pepsin for $4 \mathrm{~h}$ at $37^{\circ}$ in $0.05 \mathrm{M}$ acetate $(\mathrm{pH}=4.0$; ratio protein: enzyme $=$ I00:I). Digestion was stopped by raising the pII to 6.o. The supernatant obtained by centrifuging for ro min at roooo $\times g$ no longer contained any original protein, as shown by ultracentrifuge and immunoelectrophoresis experiments (Fig. 2).

A peptide containing the antigenic determinant was isolated from the peptic digest in the following manner. The supernatant containing the digest was incubated 
with antiserum to the original homologous Bence Jones protein No. I25 (I ml of antiserum per $\mathrm{mg}$ protein in the digest) for $\mathrm{I} h$ at $37^{\circ}$, followed by $20 \mathrm{~h}$ at $4^{\circ}$. A small precipitate was formed which was spun down and washed thrice with o.I4 $M \mathrm{NaCl}$. After dissociating the complex with I $N$ acetic acid ( $20 \mathrm{~h}$ at $4 \%$ ), followed by centrifugation at $10000 \times g$ for Io min, the supernatant was subjected to high-voltage paper electrophoresis. A peptide which had been dissociated from the precipitate could thus be detected (Fig. 3). It was eluted from the paper with water.

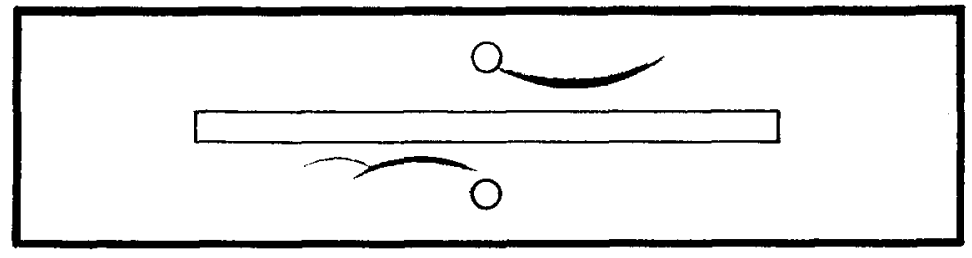

Fig. 2. Diagram of immunoelectrophoresis of Bence Jones protein No. I25 and its pepsin digest. Antiserum: anti-Bence Jones No. 125. Above: Bence Jones protein; below: pepsin digest.

By repeating this experiment several times a sufficient amount of the peptide material could be collected for further analysis. The combined eluates were concentrated and once more subjected to high-voltage electrophoresis. The product was eluted, concentrated, and analysed for amino acid composition. It contained aminoethyl cysteine. Column 6 of Table I gives the total composition, based on the presence of one aminoethyl cysteine residue.

For comparison, the composition of Hilschmann's ${ }^{8} \mathrm{COOH}$-terminal peptide $\mathrm{P}_{4}$ is also given in Table I (column 7). It can be seen that there is a very satisfactory agreement. However, our peptide contains a surplus of one each of the residues asp, ala, ileu, leu and tyr. It cannot yet be decided whether our peptide is this much longer than Hilschmann's, or whether with our complete anti-Bence Jones serum we have concomitantly isolated an antigenically active pentapeptide, derived from another part of the chain. At first sight the latter conclusion might seem to be confirmed by the appearance of a second faint precipitation line in the immunoelectrophoretic test of the total pepsin digest (Fig. 2). However, it is extremely unlikely that the reaction between a peptapeptide and antibody would lead to the formation of a precipitate. On the other hand the fact that in non-reduced Bence Jones protein No. I25 leu was found as $\mathrm{COOH}$-terminal residue (with carboxypeptidase A) argues in favour of the first proposition. But after performic acid oxidation of this Bence Jones protein cysteic acid was found as $\mathrm{COOH}$-terminal residue with carboxypeptidase $\mathrm{A}$.

We hope to clear up this uncertainty by absorption experiments with an antiserum directed against the variable part of the light chain $(=$ component $C$, see below). Should the pentapeptide be derived from this part of the chain, it would thus be removed.

\section{Identification of the low-molecular weight component}

Component $\mathrm{C}$ was obtained free from contaminating protein by gel filtration of fraction C (Fig. I) on Sephadex G-75, followed by gel filtration on Sephadex G-25.

The amino acid composition of the homogeneous protein is given in column 2 of Table I. In column 4 its number of residues have been calculated per 22000 . If 
we subtract from the composition of Bence Jones protein No. I25 (component B) the number of residues present in the constant part of the light chains according to the literature ${ }^{8}$, we obtain the values per 22000 listed in column 5 . These thus represent the variable part of Bence Jones No. I25. A striking resemblance can be seen between columns 4 and 5 .
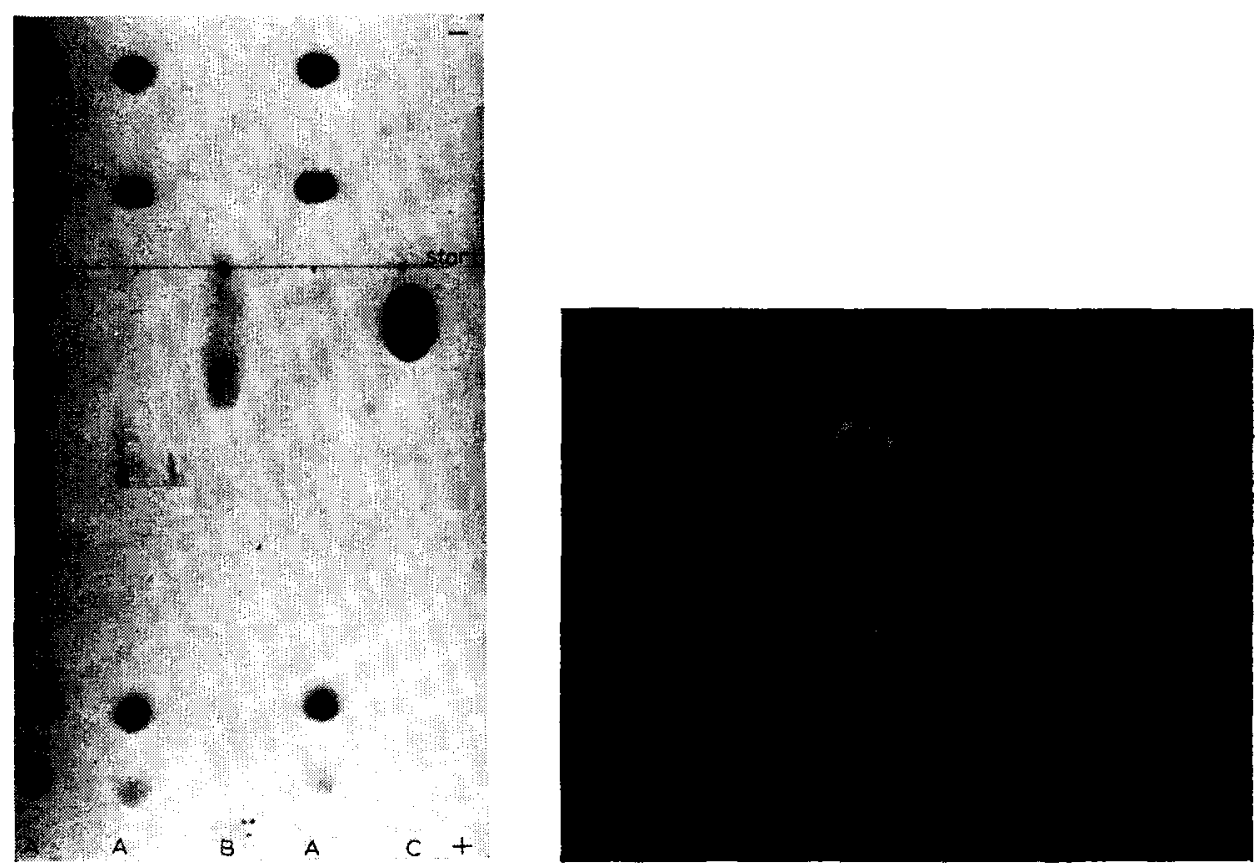

Fig. 3. High-voltage electrophoresis on paper of the immunologically active peptide. A: references (acidic and basic amino acids); B: reduced Bence Jones protein No. 125; C: peptide.

Fig. 4. Immunodiffusion test showing identity of components $B$ and $C$. Contents of wells: left: component C (peptide); right: component B (Bence Jones protein); top: antiserum against preparation of light chains; bottom: antiserum against Bence Jones protein No. I25.

In the immunodiffusion test, using antiserum against Bence Jones No. I25, component $\mathrm{C}$ gives a reaction of identity with component $\mathrm{B}$ (Fig. 4$)$. The same precipitation pattern was observed when components $\mathrm{B}$ and $\mathrm{C}$ were tested with another antiserum, directed against a different type $\mathrm{K}$ Bence Jones protein (No. I2I). Components $\mathrm{B}$ and $\mathrm{C}$ both have aspartic acid as $\alpha-\mathrm{NH}_{2}$-terminal residue. We therefore tentatively conclude that component $\mathrm{C}$ consists of a protein representing the variable part of Bence Jones No. 125 .

\section{DISCUSSION AND CONCLUSIONS}

The single aminoethyl cysteine residue found in light chains of Bence Jones No. I25 after mild reduction must correspond to the cysteine residue located near the $\mathrm{COOH}$-terminal end of the chain, forming the interchain bridge in the dimer ${ }^{\mathbf{1 4}}$. This residue is also present in the antigenically active peptide isolated from the pepsin digest of the Bence Jones protein by immuno-precipitation with antiserum directed 
against this Bence Jones protein. Therefore the antigenically active peptide is derived from the constant part of the light chain at or near the COOH-terminal end, and the antigenic determinant it bears is most likely to be the group-specific determinant $K$.

Component $\mathrm{C}$ gives a reaction of identity with component $\mathrm{B}$ in the immunodiffusion test. If, as appears likely from this work, component $C$ represents the variable part of the light chain, then the latter must also contain at least one antigenic determinant, responsible for this reaction of identity. It is not yet possible to say anything about the specificity of this determinant. It could only be tested with two antisera, and reacted with both. But it is well known that Bence Jones proteins may have other antigenic determinants in common besides the group-specific determinants $\mathrm{K}$ or $\mathrm{L}$.

\section{ACKNOWLEDGEMENTS}

We wish to thank Dr. C. H. Monfoort for performing the amino acid analyses and Prof. E. P. Steyn Parvé for her kind interest in the work. One of the authors (K.M.) is indebted to the Netherlands Government for a research fellowship.

This work has been supported by a grant from the Netherlands Organization for the Advancement of Pure Research (Z.W.O.) through the Foundation for Fundamental Medical Research (FUNGO).

\section{REFERENCES}

I L. Korngold AND R. Lipari, Cancer, 9 (I956) 262.

2 P. Burtin, L. Hartman, R. Fauvert and P. Grabar, Rev. Franç. Études Clin. Biol., I (1956) I7

3 M. Mannik and H. G. Kunkel, J. Exptl. Med., i i6 (I962) 859.

4 H. G. van Eyk and C. H. Monfoort, Biochim. Biophys. Acta, 86 (1964) $4 \mathrm{IO}$.

5 A. Solomon, J. Killander, H. M. Grey and H. G. Kunkel, Science, i 5 I (I966) 1237.

6 R. L. Nachman, R. L. Engle and S. Stein, J. Immunol., 95 (1965) 295.

7 K. Titani, E. Whitley, L. Avogadro and F. W. Putnam, Science, i 49 (1965) 1090.

8 N. Hir.schmann and L. C. C.raig, Proc. Nat. Acad. Sci. U..S., 53 (1065) I 403.

9 W. R. Gray, W. J. Dreyer and R. Hood, Science, I 55 (I967) 467.

io H. G. van Eyk, C. H. Monfoort and H. G. K. Westenbrink, Proc. Koninkl. Ned. Akad. Wetensch., Series C, 66 (1963) 345 .

I I H. G. VAN Eyk, Biochim. Biophys. Acta, 127 (1966) $24 \mathrm{I}$.

i2 H. G. van Eyk, C. Terhorst and Marlene M. A. De Vijlder, Clin. Chim. Acta, i6 (I967) 429-43I.

I 3 H. G. van Exk and J. Porath, Acta Chem. Scand., 2 I (I967) 866-872.

I C. Milstein, Nature, 307 (1966) 209.

Clin. Chim. Acta, I8 (1967) Io I-106 